\title{
Assessment of Work Productivity and Activity Impairment (WPAI) questionnaire for migraine with the help of a smartphone app
}

\author{
Avaliação do questionário Work Productivity and Activity Impairment (WPAI) \\ para enxaqueca com o auxílio de um aplicativo para smartphone \\ Renan Barros DOMINGUES ${ }^{1,2,3}$, Isabella Silva PICON ${ }^{1}$, Julia VESCOVi', Gabriel CHUNG ${ }^{2}$, \\ Felipe Teijeiro CABRAL ${ }^{2}$, Ayrton Piassi BERTELLI², Annelise Akemi Higa LEE², Paulo Diego Santos SILVA ${ }^{1}$
}

\begin{abstract}
Background: Migraine is a major cause of disability, which affects many areas of life, including productivity at work. Measuring absenteeism and presenteeism resulting from migraine with the use of appropriate tools is essential for better understanding the impact of this disease. Objective:The aim of the present study was to assess the work impact of migraine using the Brazilian Portuguese version of Work Productivity and Activity Impairment (WPAI) questionnaire. Methods: This survey was carried out with the aid of a smartphone app (Dr Cefaleia for Doctors) containing the questionnaires: ID-Migraine, Headache Impact Test (HIT-6), and WPAI. The data were collected during a headache awareness event. Correlations were assessed between migraine impact (HIT-6) with WPAl parameters: a) work time missed (absenteeism), b) impairment at work (presenteeism), c) overall work productivity loss (absenteeism+presenteeism), and d) activity impairment outside work. Results: Overall, 305 subjects with headache were interviewed and 167 were classified as having migraine. No significant differences in migraine impact according to sex $(p=0.8)$ and modality of work were registered $(p=0.8)$. Females had significantly higher absenteeism score $(p<0.001)$, but presenteeism score was not significantly different between genders $(p=0.3)$. WPAl absenteeism and presenteeism scores significantly correlated with migraine impact (HIT-6). Conclusions: The results suggest WPAl Brazilian Portuguese version was efficient in assessing migraine related work impact. The use of an app with validated questionnaires facilitates the conduction of migraine impact research in different populations, allowing a better understanding of the burden of this disease.
\end{abstract}

Keywords: Migraine Disorders; Headache, Presenteeism; Absenteism; Telemedicine.

\section{RESUMO}

Introdução: A enxaqueca é uma causa importante de incapacidade, afetando diversos domínios, incluindo a produtividade no trabalho. Avaliar o absenteísmo e o presenteísmo decorrentes da enxaqueca, por meio de ferramentas adequadas, é essencial para melhor conhecer o impacto desta doença. Objetivo: 0 objetivo deste estudo foi avaliar o impacto da enxaqueca sobre a produtividade no trabalho utilizando a versão em português do questionário Work Productivity and Activity Impairment (WPAl). Métodos: Para a realização desta pesquisa utilizou-se o aplicativo Dr. Cefaleia para Médicos com os seguintes questionários: “ID-Migraine”, "Headache Impact Test - HIT-6" e o WPAl. Os dados foram coletados durante um mutirão de conscientização sobre cefaleias. Foram avaliadas as correlações entre o impacto da enxaqueca (HIT-6) com os parâmetros do WPAl: a) tempo de trabalho perdido (absenteísmo), b) comprometimento do trabalho (presenteísmo), c) perda geral de produtividade (absenteísmo+presenteísmo), e d) comprometimento das atividades fora do trabalho. Resultados: Foram entrevistados 305 indivíduos com cefaleia, sendo que 167 dos casos foram classificados como enxaqueca. Não foram encontradas diferenças significativas no impacto da enxaqueca de acordo com o sexo $(p=0,8)$ nem a modalidade de trabalho ( $p=0,8)$. As mulheres tiveram maior absenteísmo $(p<0,001)$ mas não houve diferenças significativas entre os sexos quanto ao presenteísmo ( $p=0,3)$. Tanto os escores de absenteísmo quanto de presenteísmo do WPAl correlacionaram-se significativamente com o impacto da enxaqueca (HIT-6). Conclusões: Os resultados descritos sugerem que a versão em português do WPAl foi eficiente em avaliar o impacto no trabalho relacionado à enxaqueca. 0 uso de um aplicativo contendo questionários validados facilita pesquisas sobre o impacto da enxaqueca em diferentes populações, permitindo uma melhor compreensão do ônus resultante desta doença.

Palavras-chave: Transtornos de Enxaqueca; Cefaleia; Presenteísmo; Absenteísmo; Telemedicina.

\footnotetext{
'Santa Casa de Misericórdia de São Paulo, São Paulo SP, Brazil.

${ }^{2}$ Santa Casa de Misericórdia de São Paulo, Faculdade de Ciências Médicas, São Paulo SP, Brazil.

${ }^{3}$ Dr Cefaleia Clínica \& Telemedicina, São Paulo SP, Brazil.

Renan Barros DOMINGUES (D) https://orcid.org/0000-0002-6058-7937; Isabella Silva PICON (D) https://orcid.org/0000-0002-7944-8697; Julia VESCOVi (iD https://orcid.org/0000-0003-4569-1119; Gabriel CHUNG (D) https://orcid.org/0000-0001-8889-9919;

Felipe Teijeiro CABRAL (ID https://orcid.org/0000-0003-4406-9547; Ayrton Piassi BERTELLI (D) https://orcid.org/0000-0003-2979-0838;

Annelise Akemi Higa LEE (DD https://orcid.org/0000-0002-0796-7156; Paulo Diego Santos SILVA (DD https://orcid.org/0000-0002-5284-4526

Correspondence: Renan B. Domingues; E-mail:contato@renandomingues.med.br

Conflict of interest: There is no conflict of interest to declare.
}

Received on September 13, 2019; Received in its final form on November 28, 2019; Accepted on December 15, 2019. 
Migraine is a very frequent disorder with high impact on quality of life and work activities ${ }^{1,2,3}$. The migraine impact on work productivity can be evaluated by two variables, absenteeism and presenteeism. The latter is defined by working while sick, causing loss of productivity, worsening of health conditions of the worker, and costs ${ }^{4}$. The overall average of lost working days due to migraine is 4.4 workdays per year and the average worked days with reduced productivity is 11.4 days per year ${ }^{5}$. The most important determinant of migraine burden is presenteeism ${ }^{5}$. A recent study in 11 countries showed that the overall work impairment due to migraine in subjects with $\geq 4$ migraine days each month was found in $52 \%$ of the subjects, being more attributable to presenteeism than absenteeism ( 48 vs. $13 \%$, respectively) ${ }^{6}$.

Assessing presenteeism is more difficult than assessing absenteeism; therefore, the use of validated and standardized scales is desirable. Work Productivity and Activity Impairment (WPAI) questionnaire measures the effect of different health conditions on work productivity, generating scores for absenteeism, presenteeism, absenteeism plus presenteeism, and activity impairment outside work ${ }^{7,8}$. WPAI has been validated in several different languages, including Brazilian Portuguese 9 . The WPAI can be adapted to a specific disease or health problem and was previously used in studies assessing migraine impact, but no previous studies have used this questionnaire to assess impact on work due to migraine in Brazil ${ }^{10}$.

The contribution of mobile apps in the study of migraine has been assessed, showing potential contribution in the assessment of this disease ${ }^{11}$. In the present study, we assessed the work impact of migraine using a smartphone app that was specifically developed for headache impact surveys.

\section{METHODS}

\section{Population}

The data were collected during a headache awareness event that was carried out in three subway stations in the city of São Paulo, Brazil. The participants were informed about research, were asked to sign an informed consent form, and answered the questionnaires to the interviewers, who were medical students or Neurology residents at "Santa Casa de Misericórdia de São Paulo", Brazil. During the event, the participants received educational information regarding headaches. This study was approved by “Santa Casa de Misericórdia de São Paulo" Ethics Committee on Human Research.

\section{APP}

The app "Dr Cefaleia" for doctors was used. We developed an app functionality that was specifically designed to conduct research on headache impact. This app was created by one of the authors (RBD) and developed by R2T Rebel Thinking Tech developers. The interviewers downloaded the app in their smartphones, and use permission was given for the involved researchers. Sociodemographic information, including age, sex, and work activities were collected. The work activities were classified as employee (full time or part-time) or self-employed. After this first step, the following questionnaires were applied with the app: ID migraine, in its validated Brazilian Portuguese version $^{11,12,13,14}$, Brazilian Portuguese validated Headache Impact Test (HIT-6) ${ }^{15,16}$, and Brazilian Portuguese migraine/ headache WPAI .

The questionnaire answers were stored in the Cloud with encrypted personal data, automatically generating datasheets that were further statistically analyzed.

\section{Data analysis}

Socio-demographic data were expressed as mean \pm SD or percentages. The headache was considered as migraine in subjects who answered "Yes" to at least two out of the three questions of the Migraine ID-questionnaire ${ }^{11,12,13,14}$. Only data from subjects considered to have migraine were included in the present analysis. Normality of data was assessed with the Kolmogorov-Smirnov test and mean comparisons were performed with the Stundent's $t$ test. Pearson's correlation test was used to assess the correlation between HIT-6 score with the four scores obtained with WPAI: work time missed (absenteeism), impairment at work (presenteeism), overall work productivity loss (absenteeism+presenteeism), and activity impairment outside the work.

\section{RESULTS}

The use of the app was considered easy by the interviewers and the interviews lasted less than 15 minutes. All the questionnaires were completed successfully, and no interview was interrupted due to technical issues.

Overall, 305 subjects were interviewed during the awareness event and 167 of them were classified as having migraine. Among them, $72.9 \%$ were women, aged $32.4 \pm 11.1$ years. Thirty-two migraine subjects were excluded of WPAI analysis because they declared no work activity. Figure 1 shows a flow-chart describing all the steps of the study with the number of included and excluded subjects in each step. The mean HIT- 6 of the studied population was $63.4 \pm 9.0$ (range 33 to 78). No significant difference in HIT-6 of female (64.5 \pm 8.6$)$ and male (59.7 \pm 8.5$)$ subjects was found $(\mathrm{p}=0.8)$. The modality of work did not significantly affect HIT-6 either, being $63.8 \pm 9.0$ for employees and $59.3 \pm 8.2$ for selfemployed $(\mathrm{p}=0.8)$.

The WPAI parameters are shown in Table 1. No significant differences of WPAI scores were found between employees 
and self-employed. Female subjects had significantly higher absenteeism due to migraine, but the scores of presenteeism and absenteeism+presenteeism were not significantly different between men and women ( $\mathrm{p}=0.27$ and 0.30 , respectively). No differences in WPAI scores were found according to the modality of work. All four WPAI scores were significantly correlated with HIT-6 (Figure 2).

\section{DISCUSSION}

Assessing the loss of work productivity due to migraine is difficult. However, this is a very relevant topic since migraine

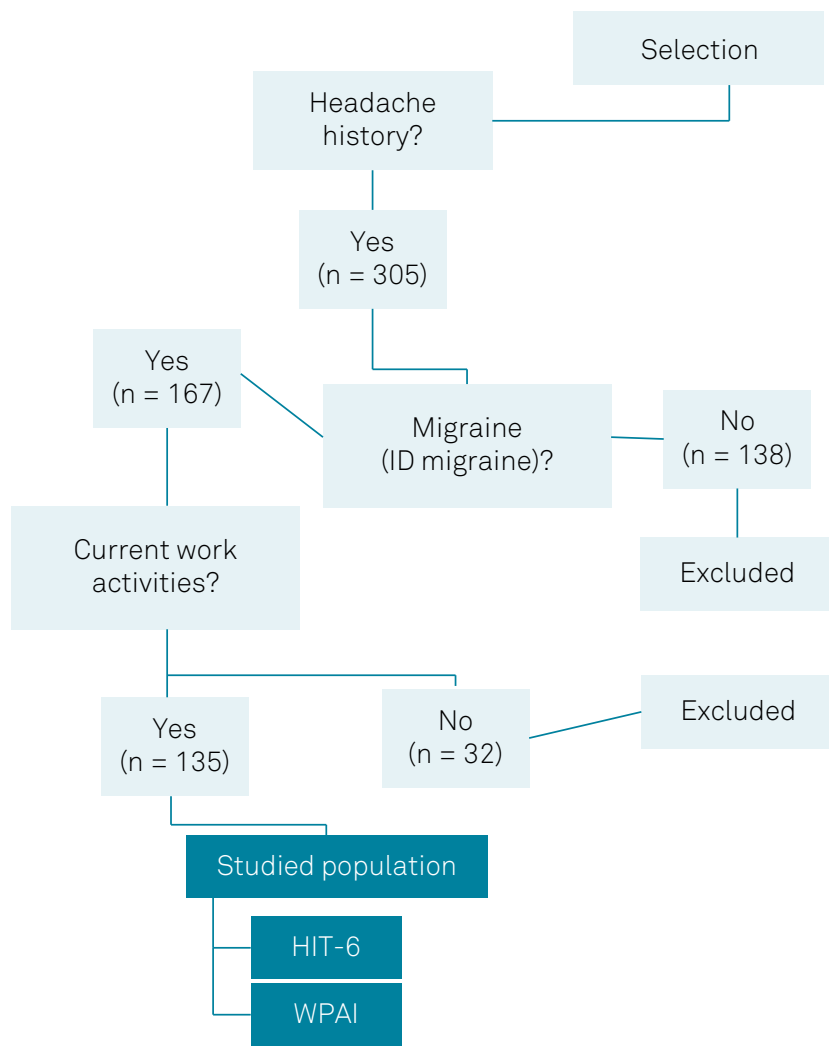

Figure 1. Flow-chart with all the steps of the study and the number of included and excluded subjects in each of the steps. is one of the most burdensome neurological diseases ${ }^{5,17,18}$. In the present work, we employed some validated questionnaires and we used an app specifically developed for this type of survey. The use of this tool facilitated the conduction of the survey. The precise time of interviews could not be assessed since they were carried out during an awareness event and, besides the interviews, the participants received information about headache treatment by the interviewers. The datasheets with survey results were automatically generated, facilitating data analysis. Besides being directly used by the interviewers, the content of the app can also be delivered by mail to the interviewees, as well as being programmed for being downloaded in the smartphone of predetermined groups of interviewees. This is possible with simple technological adaptations since all the questionnaires are selfassessment tools.

Previous studies have assessed the use of technology in clinical and research activities related to headache. The use of telemedicine showed to be efficient and safe in the followup of patients with headache $e^{19,20,21}$. These studies employed telemedicine equipment or computer programs dedicated to telemedicine ${ }^{19,20,21}$. Smartphone technology has been used for headache diaries, behavioral interventions, and electronic monitoring of headaches ${ }^{22,23,24,25}$. Digital technology has the advantage of facilitating information registry, thus enabling the creation of large databases. On the other hand, they may be associated to limitations, such as the use of self-reported questionnaires. In addition, safety concerns arise so that compliance procedures should be adopted to avoid the use of data for targeted advertising ${ }^{26}$. Therefore, such devices must be tested and scientifically evaluated prior to its use and must be developed under medical expertise to be used as auxiliary tools.

WPAI is a largely used instrument with simple and objective questions. Translation, cross-cultural adaptation, and validation were already carried out in Brazilian Portuguese $^{9}$; nonetheless, this was the first study assessing migraine work and activity impairment using this tool in Brazil. Our data confirm high migraine related-work disability. There was a trend toward a greater work disability among female participants; however, the only significantly

Table 1. Work Productivity Impairment (WPAI) Migraine/Headache scores (\%) according to sex and work activity.

\begin{tabular}{lcccc}
\hline & $\begin{array}{c}\text { Work time missed } \\
\text { (absenteeism) }\end{array}$ & $\begin{array}{c}\text { Impairment at work } \\
\text { (presenteeism) }\end{array}$ & $\begin{array}{c}\text { Overall work productivity loss } \\
\text { (absenteeism+presenteeism) }\end{array}$ & $\begin{array}{c}\text { Activity impairment } \\
\text { (outside work) }\end{array}$ \\
\hline General & $0.4 \pm 1.1$ & $54.0 \pm 33.2$ & $54.7 \pm 33.4$ & $62.2 \pm 29.1$ \\
Female & $0.5 \pm 1.3$ & $59.9 \pm 32.5$ & $60.3 \pm 31.8$ & $68.2 \pm 26.5$ \\
Male & $0.0 \pm 0.2$ & $36.3 \pm 33.5$ & $36.3 \pm 33.5$ & $42.7 \pm 29.7$ \\
p-value & $<0.0001$ & 0.27 & 0.30 & 0.22 \\
Employees & $0.4 \pm 1.2$ & $57.0 \pm 32.4$ & $57.1 \pm 32.2$ & $63.8 \pm 27.8$ \\
Self-employed & $0.2 \pm 0.7$ & $36.0 \pm 34.4$ & $36.0 \pm 34.1$ & $48.6 \pm 36.4$ \\
p-value & 0.15 & 0.59 & 0.59 & 0.06 \\
\hline
\end{tabular}




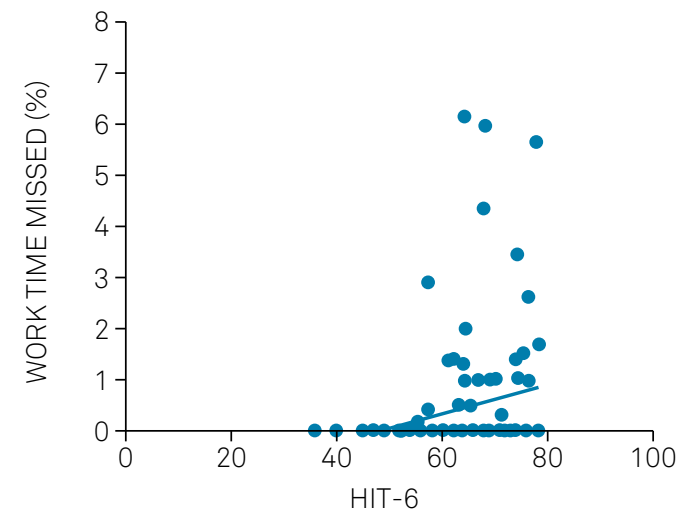

$P=0.0038$

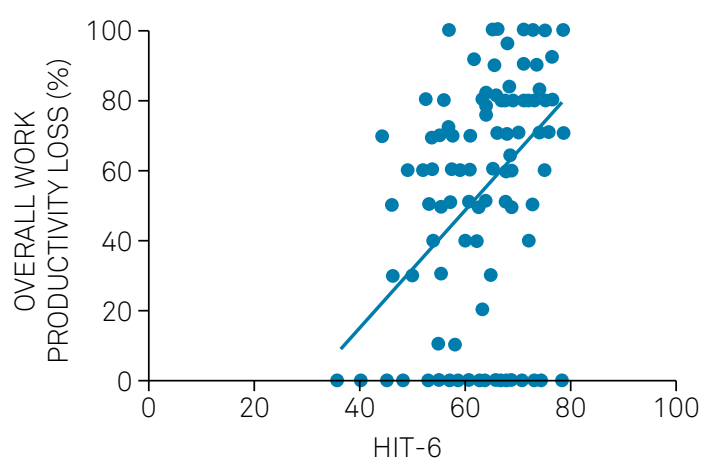

$P<0.0001$

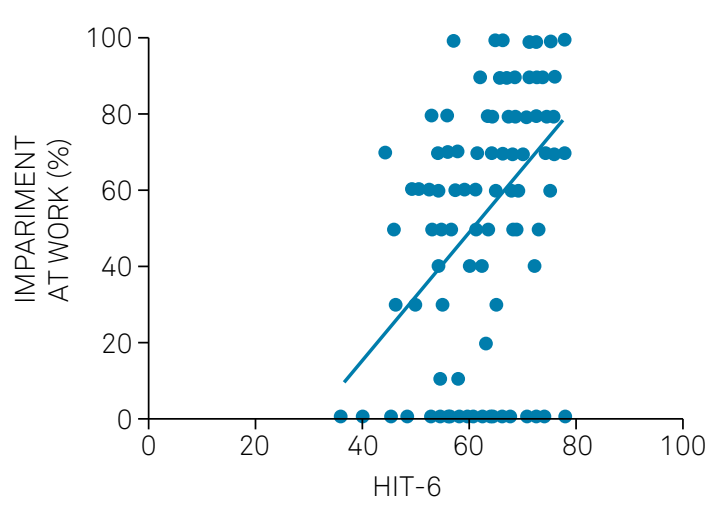

$P<0.0001$

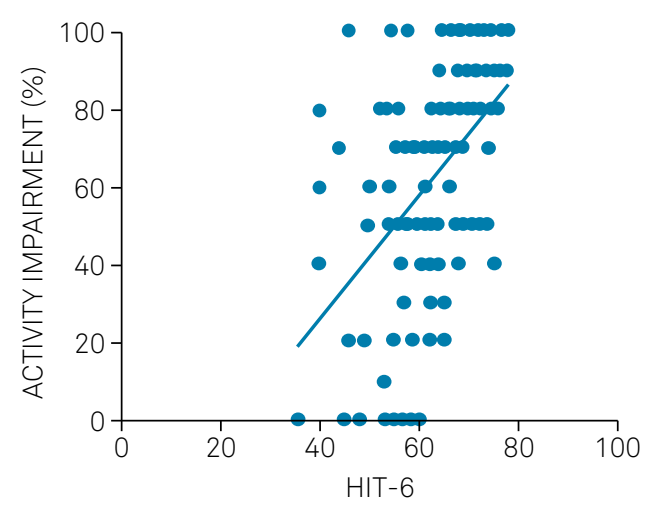

$P<0.0001$

Figure 2. Correlations between migraine impact assessed with Headache Impact Test (HIT-6) score (36-78) with the four Work Productivity Impairment (WPAI) Migraine/Headache scores (\%): Work Time Missed (absenteeism), Impairment at Work (presenteeism), Overall Work Productivity Loss (absenteeism+presenteeism), and activity impairment (percentage of daily activity impairment outside work).

higher score among women was work time missed (absenteeism). This finding is in agreement with previous works showing less migraine-related disability among $\operatorname{men}^{27}$. There were no significant migraine-related impairment differences according to the type of work activity when we compared employees and self-employed. There is still little information about the impact of migraine on work activities, and future studies are still needed to verify the migraine impact in different types of work activities ${ }^{28}$.

All the WPAI scores significantly correlated with HIT-6. HIT-6 was developed to measure a wide spectrum of factors which contribute to the burden of headache. It is therefore not surprising that we found significant correlations between all the WPAI scores with HIT-6. The advantage of WPAI is that it can be used in research, specifically evaluating the impact of migraine on work productivity and not only for general headache impact, allowing surveys inside companies, organizations, public services, or any other specific working group or population.

The limitations of the study include the cross-sectional design, precluding the establishment of any causal relationship. We did not include a large and representative Brazilian population. Other limitation is that diagnoses were based on a self-reported questionnaire and not confirmed by clinical assessment. Moreover, there was no control of potential confounding factors, such as medical comorbidities, sleep disorders, and psychiatric comorbidities. Psychiatric disorders, particularly depression, have a strong association with migraine and contribute to increase its impact and reduce quality of life when both conditions occur comorbidly ${ }^{29}$. On the other hand, conducting the study in a public place possibly prevented biases in selecting patients from headache clinics, which tend to have a higher impact and greater work impairment.

In conclusion, our data suggest that the Brazilian Portuguese version of WPAI is a good tool to assess migraine related work impairment. The use of a smartphone app contributes to quicker surveys. The combination of validated questionnaires and digital resources may facilitate research to better understand the migraine impact on the professional life of sufferers. 
1. Burch R, Rizzoli P, Loder E. The Prevalence and impact of migraine and severe headache in the United States: figures and trends from Government Health Studies. Headache. 2018 Apr;58(4):496-505. https://doi.org/10.1111/head.13281

2. Pavlović JM, Stewart WF, Bruce CA, Gorman JA, Sun H, Buse DC, et al. Burden of migraine related to menses: results from the AMPP study. J Headache Pain. 2015 Mar;16:24. https://doi.org/10.1186/ s10194-015-0503-y

3. Lipton RB, Stewart WF, Diamond S, Diamond ML, Reed M. Prevalence and burden of migraine in the United States: data from the American Migraine Study II. Headache. 2001 Jul-Aug;41(7):646-57. https://doi. org/10.1046/j.1526-4610.2001.041007646.x

4. Kigozi J, Jowett S, Lewis M, Barton P, Coast J. The estimation and inclusion of presenteeism costs in applied economic evaluation: a systematic review. Value Health. 2017 Mar;20(3):496-506. https://doi.org/10.1016/j.jval.2016.12.006

5. Leonardi M, Raggi A. A narrative review on the burden of migraine: when the burden is the impact on people's life.J Headache Pain. 2019;20(1):41. https://doi.org/10.1186/s10194-019-0993-0

6. Martelletti P, Schwedt TJ, Lanteri-Minet M, Quintana R, Carboni V, Diener HC, et al. My Migraine Voice survey: a global study of disease burden among individuals with migraine for whom preventive treatments have failed. J Headache Pain. 2018 Nov;19(1):115. https://doi.org/10.1186/s10194-018-0946-z

7. Prasad M, Wahlqvist P, Shikiar R, Shih YC. A review of self-report instruments measuring health-related work productivity: a patient-reported outcomes perspective. Pharmacoeconomics. 2004;22(4):225-44. https://doi.org/10.2165/00019053200422040-00002

8. Varela N, Guillén-Grima F, Pérez-Cajaraville JJ, Pérez-Hernández C, Monedero P. Assessment of the impact of pain on work productivity: validation of the Spanish WPAl: Pain questionnaire. An Sist Sanit Navar. 2016 Apr;39(1):77-85. https://doi.org/10.4321/\$1137$6627 / 2016000100009$

9. Ciconelli RM, Soárez PC, Kowalski CC, Ferraz MB. The Brazilian Portuguese version of the Work Productivity and Activity Impairment: General Health (WPAI-GH) Questionnaire. Sao Paulo Med J. 2006;124(6):325-32. https://doi.org/10.1590/S151631802006000600005

10. Vo P, Fang J, Bilitou A, Laflamme AK, Gupta S. Patients' perspective on the burden of migraine in Europe: a cross-sectional analysis of survey data in France, Germany, Italy, Spain, and the United Kingdom. J Headache Pain. 2018 Sep;19(1):82. https://doi.org/10.1186/ s10194-018-0907-6

11. Agosti R. Migraine burden of disease: from the patient's experience to a socio-economic view. Headache. 2018 May;58 Suppl 1:17-32. https://doi.org/10.1111/head.13301

12. Gil-Gouveia R, Martins I. Validation of the Portuguese version of ID-Migraine. Headache. 2010 Mar;50(3):396-402. https://doi. org/10.1111/j.1526-4610.2009.01449.x

13. Mattos ACMT, Souza JA, Moreira Filho PF, Jurno ME, Velarde LGC. ID-Migraine ${ }^{T M}$ questionnaire and accurate diagnosis of migraine. Arq Neuropsiquiatr. 2017 Jul;75(7):446-50. https://doi. org/10.1590/0004-282X20170069

14. Domingues RB, Domingues SA. Headache is associated with lower alcohol consumption among medical students. Arq Neuropsiquiatr. 2011 Aug;69(4):620-3. https://doi.org/10.1590/s0004$282 \times 2011000500009$
15. Domingues RB, Teixeira AL, Domingues SA. Physical practice is associated with less functional disability in medical students with migraine. Arq Neuropsiquiatr. 2011 Feb;69(1):39-43. https://doi. org/10.1590/s0004-282×2011000100009

16. Martin M, Blaisdell B, Kwong JW, Bjorner JB. The Short-Form Headache Impact Test (HIT-6) was psychometrically equivalent in nine languages J Clin Epidemiol. 2004 Dec;57(12):1271-8. https://doi. org/10.1016/j.jclinepi.2004.05.004

17. Domingues RB, Domingues SA, Lacerda CB, Machado TV, Duarte H, Teixeira AL. Alcohol use problems in migraine and tension-type headache. Arq Neuropsiquiatr. 2014 Jan;72(1):24-7. https://doi. org/10.1590/0004-282X20130186

18. Raggi A, Covelli V, Guastafierro E, Leonardi M, Scaratti C, Grazzi L, et al. Validation of a self-reported instrument to assess work-related difficulties in patients with migraine: the HEADWORK questionnaire. J Headache Pain. 2018 Sep;19(1):85. https://doi.org/10.1186/ s10194-018-0914-7

19. Müller KI, Alstadhaug KB, Bekkelund SI. Telemedicine in the management of non-acute headaches: A prospective, openlabelled non-inferiority, randomised clinical trial. Cephalalgia. 2017 Aug;37(9):855-63. https://doi.org/10.1177/0333102416654885

20. Qubty W, Patniyot I, Gelfand A. Telemedicine in a pediatric headache clinic: A prospective survey. Neurology. 2018 May;90(19):e1702-e05. https://doi.org/10.1212/WNL.0000000000005482

21. Friedman DI, Rajan B, Seidmann A. A randomized trial of telemedicine for migraine management. Cephalalgia. 2019 Oct;39(12):1577-85. https://doi.org/10.1177/0333102419868250

22. Stubberud A, Linde M. Digital technology and mobile health in behavioral migraine therapy: a narrative review. Curr Pain Headache Rep. 2018 Jul;22(10):66. https://doi.org/10.1007/s11916-018-0718-0

23. Bandarian-Balooch S, Martin PR, McNally B, Brunelli A, Mackenzie S. Electronic-Diary for Recording Headaches, Triggers, and Medication Use: Development and Evaluation. Headache. 2017 Nov;57(10):1551-69. https://doi.org/10.1111/head.13184

24. Mosadeghi-Nik M, Askari MS, Fatehi F. Mobile health (mHealth) for headache disorders: A review of the evidence base. J Telemed Telecare. 2016 Dec;22(8):472-7. https://doi. org/10.1177/1357633×16673275

25. Tassorelli C, Jensen R, Allena M, De Icco R, Katsarava Z, Miguel Lainez J, et al. The added value of an electronic monitoring and alerting system in the management of medication-overuse headache: A controlled multicentre study. Cephalalgia. 2017 Oct;37(12):1115-25. https://doi.org/10.1177/0333102416660549

26. Minen MT, Stieglitz EJ, Sciortino R, Torous J. Privacy issues in smartphone applications: an analysis of headache/migraine applications. Headache. 2018 Jul;58(7):1014-27 https://doi. org/10.1111/head.13341

27. Scher Al, Wang SJ, Katsarava Z, Buse DC, Fanning KM, Adams $A M$, et al. Epidemiology of migraine in men: Results from the Chronic Migraine Epidemiology and Outcomes (CaMEO) Study. Cephalalgia. 2019 Feb;39(2):296-305. https://doi. org/10.1177/0333102418786266

28. Raggi A, Covelli V, Leonardi M, Grazzi L, Curone M, D’Amico D. Difficulties in work-related activities among migraineurs are scarcely collected: results from a literature review. Neurol Sci. 2014 May;35 Suppl 1:23-6. https://doi.org/10.1007/s10072-014-1736-2

29. Burch RC, Buse DC, Lipton RB. Migraine: epidemiology, burden, and comorbidity. Neurol Clin. 2019 Nov;37(4):631-49. https://doi. org/10.1016/j.ncl.2019.06.001 